

\title{
The Importance of Economic Security in Shaping Cultural Be- haviors Influenced by Progressive Globalization Processes
}

\author{
Daniel KUCHAREK, \\ Military University of Aviation, Dęblin, Poland, e-mail: d.kucharek@law.mil.pl. \\ ORCID: 0000-0001-5968-8610
}

DOI: https://doi.org/10.37105/sd.76

\begin{abstract}
One of the most transparent manifestations of globalization processes currently occurring is the phenomenon of economic migration. It is associated with the movement of large masses of people from poor, economically underdeveloped regions often disturbed by armed conflicts to economically developed countries with already shaped prosperity. Migration processes pose many economic, social and cultural problems that discourage the population of wealthy countries from receiving incoming migrants. This article was organized in order to firstly consider the impact of economic migration on the phenomenon of changes in the population structure and thus cultural changes that might result from it. The next stage of the conducted analysis refers to the problem of commodification of artworks created within the area of culture. An important effect of the conducted research is to draw attention to the phenomenon of blurring differences, and, as a result, the emergence of widely accepted, supranational cultural patterns. Finally, the undertaken research identifies possible opportunities and threats for sustainable development of culture on an economically diverse world.
\end{abstract}

Keywords: economic security, culture, migration, safety. 


\section{Introduction}

Economic security is a concept without a clearly interpreted definition. Due to this reason, many experts on security come up with their own terms, quite often referring them to state internal and international security in terms of economic dependence. The latter term covers economic aspects operating based on existing interstate, regional and global connections. Generally, it can be said that it concerns relations between countries (regions) most often represented in a form of the pursuit of economic dominance of developed countries over economically weaker states. On the other hand, domestic economic security can be considered as striving to preserve (and develop) national security, and thus promote the economic interest of the state. Secondary but more colloquial concept of domestic economic security can be defined in terms of the level of wealth of society. Predominantly such concept relates to the security of the economic existence of individuals operating within households.

The aim of the following article is to present and assess the impact of the level of wealth of societies on the formation of selected cultural processes in an integrating world. The motivation behind commencing such research was the currently increasing phenomenon of economic migration, which also became the main analysis issue. Another important aspect is the commercialization of cultural products as a result of the impact of globalization on the preservation of traditional cultural values.

\section{Economic migration process}

Migration processes occur mainly due to the increasing economic differences between highly and underdeveloped countries. Mi- gration causes are also associated with demographic problems, cataclysms or social unrest (such as revolutions, wars, dictatorships, etc.) (Nikulin, 2015). Based on research conducted by the European Statistical Office, it was found that as many as 4.7 million people immigrated to the European Union Member States in 2015. In addition, over 1.9 million people who previously resided in one of the EU member states moved to another (wealthier) member state. On a global scale, migration processes related to the intention to improve living standards mainly concern such countries as the United States, Australia, Germany, Great Britain, France, Canada or the United Kingdom. The influx of a large number of migrants has a direct impact on the ongoing changes in the current population structure (Kuciński, 2004). This particularly affects small and medium-sized countries, which are very sensitive to changes taking place in this respect. For example, in Switzerland as many as 15\% of the population is foreign while in France $20 \%$ out of 80 million citizens are refugees (Statystyka, 2019).

The influx of such a significant number of people from the outside the currently functioning cultural circle may bring severe changes in the way existing social norms are shaped. As a result, such changes might further translates into the spread (penetration) of altered and sometimes even new cultural patterns. Immigrants, especially those arriving from countries of a different religion, are mostly not susceptible to rapid assimilation with the local community. Together with the occurrence of intolerance to the differences presented by migrants, the creation of ghettos that are even more closed to integration processes might occur. In such a situation, even a significant improvement in the standard of living is not a sufficient factor for the acceptance of existing social norms by arriving people (Sullivan, et al., 2018). Growing antagonisms, usually for religious reasons might lead to the "separation of certain communities" and focusing on their own culture 
sometimes very foreign to the values of the migrants receiving countries (Grosse, 2018).

Recently, a huge influx of culturally different people from Africa and the Middle East to Western Europe took place. Those cultural groups are characterized by a high population growth and it may happen in the future that they will become the dominant group in some countries. Additionally, this is favored by low birth rates and secularization combined with a very high tolerance to cultural differences in economically developed countries. What is more, a kind of "laziness" on the part of rich societies might be noticed across well developed countries. This mainly results from the awareness that existence in prosperity is something natural, something that should not be sought, because it has been given to them for centuries. Such an attitude often causes the radicalization of cultural behaviors in these societies. It manifests itself in the search for an alternative to consumption behavior through the involvement of young people in the activities of extreme religious movements, anti-globalization or activities related to environmental protection. On the other hand, completely different behavior characterizes the inflow population. Consolidation processes are visible among these communities based on cultivating a common religion and traditional patterns of behavior (clothing, food, celebrating holidays, etc.) (Kucharek, 2016).

By analyzing the problem of the inflowing economic migrants to countries with a high level of economic security, it might be argued that it is the wealth possessed that contributes to the growing difficulties in maintaining European cultural identity. Of course, the solutions to the problem cannot involve any measures aiming to reduce the wealth of economically developed countries in order to reduce their attractiveness to migrants. However, a policy should be pursued aiming to maintain and preserve the wealth of European cultures. So far, however, no effective ways have been developed to deal with the growing problems of the inflow of large numbers of economic migrants. On the other hand, the isolationist policy used in many countries, i.e. the construction of border walls and the introduction of administrative barriers to the admission of new migrants may only partially reduce their inflow but will not tackle the existing problem.

\section{Culture as a commercial product}

Cultural patterns currently spread around the world are mainly based on information provided by the mass media. As expected, they contribute to the creation of mass culture mainly focusing on increasing the viewership of specific programs or TV channels. Culture has become a product susceptible to the current demand of recipients to whom specific content is targeted, e.g. advertisements. Financing the creation of artistic works, based on the commercially shaped tastes of recipients, can lead to significant restrictions in the quality of created works. Very often, the main idea of new songs comes down to a message that is easy to perceive without requiring the public to have more general knowledge, experience, tastes and sensitivity for their proper interpretation. As a result, it leads to the shallowing of the value of human talent with commercial requirements. The works of artists are then created not according to what they consider important, but by focusing on maximum satisfaction of the mass audience (Cho, 2019).

As a result, it should be considered to what extent the financial support granted by state institutions and patronage of private donors can contribute to the creation of a greater number of works which are currently considered to be more artistically valuable. It has to be highlighted that very often the demand for elite culture is limited to only selected groups of recipients with broad cultural competences and thus it requires constant subsidizing. Statistically, the limited 
number of recipients of high culture in comparison with the wide audience of mass culture can lead to the marginalization of creativity that brings higher cultural values.

On the other hand, accusing solely contemporary artists of being guided by commercialism in the process of creating culture is certainly unfair. It should be noted that meeting the existing demand for cultural goods inspired by financial resources has always been a common practice. Artists used financial gains often as inspiration for actions whose primary goal was to satisfy the patron of their talent. Striving to please his protector was often reduced to the creation of distinguished works currently regarded as the most valuable products of human culture. On the other hand, activities aimed at attracting attention at all costs, which today can be described as commercial activities, resulted in the creation of works of very mediocre artistic quality (e.g. panegyrics).

When considering the impact of economic commercialization on current cultural progress, one should take into account its great importance for initiating actions that result in the creation of a huge number of works. It should be noticed that commercialization reduces culture to a commodity dependent on the market price, while artistic values may be of merely secondary importance. This leads to the occurrence of circumstances in which the freedom of creative activity is limited and the artist's sole role is to meet the expectations of buyers. Nevertheless, even in such a case, the level of creativity required to create the products is very diverse, and it still enriches the cultural resources of the nation, state and the world.

\section{Blurring cultural boundaries}

The availability of information on a massive scale as a result of global communication causes cultural processes to focus on ex- ternal patterns that have quite often been alien to a given society or a group. The interpenetration of cultures has been a natural occurrence within lives of the entire societies, tribal groups and even family groups since the very beginning of human civilization. However, it was never as violent as it is today and did not affect the recipients of the transmitted content on such a massive scale. Nowadays there are many aspects influencing the existing fascination with information provided by the mainstream media. The most important one is that presented information create a picture of a better world with the fullness of material goods surrounding people. In such way, certain behavioral models are passed on and at the same time willingly adopted by the recipients. Even though, that imposed models are often vastly different from the ideals cultivated so far in a targeted society (Kisiel, 2005).

Globalization has accelerated the process of creating a transnational culture shaped primarily by economic factors. The generated idea of the prosperous world based mainly on Anglo-Saxon models translates not only into the adoption of English as an international language, but also includes rules of conduct, expressions, and finally the celebration of holidays associated so far only with Anglo-Saxon culture. As a result, we can observe for example young people in Asian countries behaving and dressing like their American idols. American mass culture is also very popular in Muslim countries despite recognizing United States as a very hostile state. Especially the young generation living in larger cities is opening up to Western cultural influences despite stigmatizing American values not only by state and religious authorities but also by law.

The global unification of cultural values is just beginning to shape a new, transnational culture. It might be assumed that in the future it will have a multidimensional character leading to abandonment of current cultural patterns causing them initially to be marginalized by society until finally fading away. Small national communities, hardly 
able to resist cultural absorption by economically stronger neighbors, are particularly vulnerable to such processes. In such case, global unification become an undesirable phenomenon leading to the impoverishment of cultural diversity in the world. However, the positive aspects of popularizing Western values should be also highlighted. They accelerate the democratization of states, which is manifested in the people's attempts to free themselves from the influence of dictatorial regimes or impractical religious orders. In this respect, the impact of publicly available mass media may bring results much better than forced implementation of democratic solutions as was attempted in case of Iraq and Afghanistan.

\section{Summary}

The existing links between the level of wealth of the society (economic security) and the cultural processes taking place are not a new phenomenon. They were observed already in ancient times since the emergence of trade within formerly known world. Contacts initiated by the need for trade enabled the transfer of tangible and intangible products of human activity. However, the emerging dependencies in this area, along with the progressing globalization, have intensified and are constantly spreading throughout the world. The currently observed processes of economic migration threaten existing cultural values as never before. Difficulties associated with the assimilation (especially in Europe) of the population coming from Africa and the Middle East may as a consequence lead to the slow transformation of some countries into countries with the dominance of the Muslim religion and its cultural values.

It should be noted that the massive influx of migrants to economically developed countries is due to the ubiquitous pursuit of the
Western standards of living. The propagation of Anglo-Saxon culture is not only the promotion of democracy, but above all, the wealth of Western societies. What is more, all behavioral patterns presented by the mass media are being uncritically accepted. By promoting such image, a new media culture emerges most often detached from its own sometimes even millennium-long cultural heritage. Currently, a multifaceted phenomenon of the impact of the wealth of societies on emerging cultural processes can be noticed. On the one hand, we are observing the influx of economic migrants to economically developed countries and related problems of cultural identity. On the other hand, rich countries (especially Anglo-Saxon) culturally influence most of the modern world through the means of the mass media. So, there is a certain paradox when culturally threatened countries pose similar threat to regions that are the source of migration. Of course, this interpretation of the problem analyzed in this article is very simplified. It should be highlighted that the creation of the Western world as an enclave of prosperity will results in the intensification of economic migration. In such a situation, a rhetorical question arises: Is it possible and necessary to undertake actions in order to limit the spread of commercial vision of the Western world?

The problems discussed in this article regarding the impact of economic security on the development of selected cultural processes constitute only a small scope of the existing threats to cultural identity. Such issues are always associated with great complexity, which results in enormous difficulties in identifying good solutions that could eliminate or limit the negative effects on the comprehensive development of world culture. It should also be noted that the phenomena discussed in this article are currently very dynamic. As a result, they will remain to be a very interesting and important topic of social research. 


\section{References}

1. Kisiel P. (2005). Globalization and artistic culture, Argumenta Oeconomica Cracoviensia, no. 3, , Cracow: University of Economics pp. 87-100.

2. Grosse T. (2018), Chwiejna potęga, Rzeczpospolita, no. 208, Warszawa: Gremi Media SA.

3. Kucharek D. (2010). Financial problems with Greece and Spain Influence on Stock Exchanges trade in Central Europe. Global Economic Crisis and Changes. Silesian University in Opava School of Business Administration in Karvina, Karvina.

4. Kucharek D. (2012). Wptyw zarzqdzania finansami publicznymi na koniunkture gietdowa $w$ wybranych krajach Unii Europejskiej, Skrzypek E. (Eds.), Integracja zarządzania $\mathrm{w}$ warunkach GOW Lublin: Wydawnictwo UMCS, pp. $109-121$.

5. http://ec.europa.eu/eurostat /statisticsexplained/index.php?title=Migration_and_migrant_population_statistics/pl [access: 23.02.2020].

6. Kuciński K. (2004). Migracje w teorii ekonomii, Zeszyty Naukowe Szkoty Gtównej Handlowej, Volume 15, pp. 8-20.

7. Nikulin E. (2015) Globalizacja a zarys bezpieczeństwa państw, Jemioło T. and Rajchel K. (Eds.), Bezpieczeństwo narodowe i zarządzanie kryzysowe w Polsce w XXI wieku, Warszawa: AON.

8. Nowa Encyklopedia Powszechna $P W N$. (1995). tom 3, Warszawa: Wydawnictwo Naukowe PWN.

9. Statystyka dotycząca migracji i populacji migrantów, Eurostat, Retrieved from http://ec.europa.eu/eurostat/statisticsexplained/index.php/Migration_and_migrant_population_statistics/pl [access: 23.10.2019].
10. Sullivan P. L., Blanken L. J., Rice I. C. (2018) Arming the Peace: Foreign Security Assistance and Human Rights Conditions in Post-Conflict Countries, Defence and Peace Economics, Volume 31, pp. 177-200. DOI:10.1080/10242694.2018.15583 88.

11. Cho W. (2019) Making Dictators' Pockets Empty: How Do U.S. Sanctions Influence Social Policies in Autocratic Countries?. Defence and Peace Economics, Volume 30 (pp. 648-665), DOI:10.1080/10242694.2017.13928 32. 